\title{
Correlation between Age, Gender, Occupation, Residential Area, and the Occurrence of Eyelid Tumor in Medan, Indonesia
}

\author{
Lulu Anandita Putri ${ }^{1}$, Rodiah Rahmawaty Lubis ${ }^{2 *}$ \\ ${ }^{1}$ College of Medicine, Faculty of Medicine, Universitas Sumatera Utara, Medan, Indonesia; ${ }^{2}$ Department of Ophthalmology, \\ Faculty of Medicine, Universitas Sumatera Utara, Medan, Indonesia
}

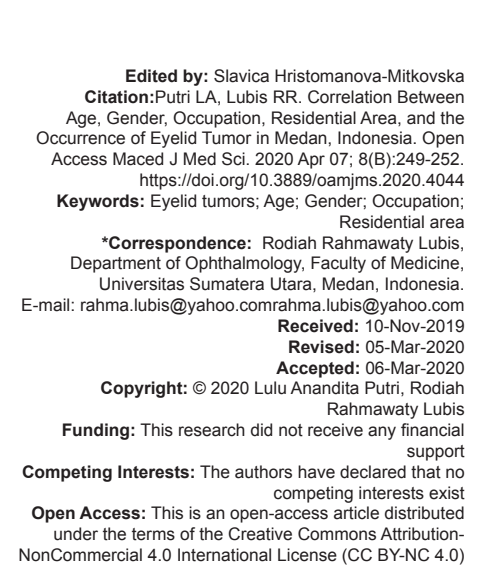

Introduction

Tumors can appear throughout the body, including the eyelids. The appearance of the tumor can originate from organs around the eyelids (skin, muscles, glands, etc.), but mostly originates from the epidermis and can be benign or malignant [1].

The development of eyelid tumors can be affected by various risk factors such as age, gender, residential area, occupation, and various other things. From research conducted by Gundogan in Ankara, the majority of patients aged over 40 years [2], while research in Bali states that the most age groups are in the age range of 61-70 years [3]. The incidence of eyelid tumors seen from gender has different results in each country, for example, in India, it was found that most of them were women, while in Bali, Indonesia, the majority are male [4], [5]. Based on the type of work, eyelid tumors are usually found in people who often work or do activities outside and the incidence will increase in people living in the highlands and equatorial regions [6].

Due to this, the study was conducted with the aim of finding a relationship between age, gender, residential area, occupation, and the occurrence of eyelid tumors.

\section{Subjects and Methods}

This study used an analytic study with a cross-sectional approach. We used total sampling as the sampling technique. Data were taken from RSUP Haji Adam Malik medical records from January 2014 to June 2018 . The population was all outpatient and inpatient diagnosed with eyelids tumor with total sample 111 patients. Variables independent in this research were (1) age (2) gender (3) occupation, and (4) residential area and variables dependent were malignant eyelid tumors and benign eyelid tumors. The inclusion criteria in this study were all inpatients and outpatients who had been diagnosed with an eyelid tumor and had the results of pathological anatomy and or radiology examination. The exclusion criteria were patients with orbital tumors, conjunctival tumors, corneal tumors, scleral tumors, and uvea tract tumors.

This research has received permission from Health Research Ethical Committee of the Faculty of Medicine, Universitas Sumatera Utara, and also RSUP Haji Adam Malik has also given permission to conduct research at the hospital. 


\section{Statistical analysis}

SPSS version 17.0 was used as the application to analyze the medical records in this study. This study used Chi-square to see the results of bivariate analysis, then to see the strength of the correlation between the dependent variable and the independent variable, the authors used the contingency coefficient. In this study, a prevalence ratio with a clinical incidence $(\mathrm{Cl})$ of $95 \%$ was sought to find out how much risk factors between age, gender, occupation, residential area, and the occurrence of eyelid tumors.

\section{Results}

From 111 medical records, malignant eyelid tumors were the most common, which were generally benign cell carcinoma (BCC), as many as 30 cases $(27 \%)$ and then followed by squamous cell carcinoma, melanoma, and sebaceous carcinoma. As for benign eyelid tumors, cysts are the most common case. Twenty cases $(18 \%)$ were found in Table 1.

\begin{tabular}{|c|c|}
\hline Eyelid lesions & $\mathrm{n}(\%)$ \\
\hline \multicolumn{2}{|c|}{ Malignant eyelid lesions } \\
\hline$B C C$ & $30(27)$ \\
\hline SCC & $19(17.1)$ \\
\hline Melanoma & $10(9)$ \\
\hline SBC & $1(0.9)$ \\
\hline \multicolumn{2}{|l|}{ Benign eyelid lesions } \\
\hline Cyst & $20(18)$ \\
\hline Xanthelasma & $11(9.9)$ \\
\hline Papilloma & $6(5.4)$ \\
\hline Hemangioma & $4(3.6)$ \\
\hline Neurofibromatosis & $4(3.6)$ \\
\hline Nevus & $2(1.8)$ \\
\hline Fibroma & $2(1.8)$ \\
\hline Lipoma & $2(1.8)$ \\
\hline Total & $111(100)$ \\
\hline
\end{tabular}

Based on gender, eyelid tumor patients are dominated by women, as many as 75 people (67.6\%). The most common age group with eyelid tumors is 51-60 years, as many as 34 people (30.6\%). Many patients who suffer from eyelid tumors reside in lowland areas, which is Medan city, as many as 24 people $(21.6 \%)$. Moreover, as many as 38 people $(34.2 \%)$ are found working as housewives (indoor workers). The results of these data are shown in Table 2.

Based on the results of the Chi-square test, there was a correlation between the occurrence of an eyelid tumor and occupation ( $p \leq 0.05)$ and there was a correlation between the occurrence of eyelid tumors and age groups ( $p \leq 0.05)$. For the contingency coefficient test, it was found that the relationship between eyelid tumors and the age group had moderate strength. Besides, there are also shown the results of the prevalence ratio in Table 3.
Table 2: The characteristics distribution of patients with eyelid tumors based on gender, age group, residential area, and occupation

\begin{tabular}{|c|c|}
\hline Characteristics & $\mathrm{n}(\%)$ \\
\hline \multicolumn{2}{|l|}{ Gender } \\
\hline Male & $36(32.4)$ \\
\hline Female & $75(67.6)$ \\
\hline \multicolumn{2}{|l|}{ Age group } \\
\hline $1-10$ & $3(2.7)$ \\
\hline $11-20$ & $7(6.3)$ \\
\hline $21-30$ & $8(7.2)$ \\
\hline $31-40$ & $13(11.7)$ \\
\hline $41-50$ & $17(15.3)$ \\
\hline $51-60$ & $34(30.6)$ \\
\hline $61-70$ & $15(13.5)$ \\
\hline$>70$ & $14(12.6)$ \\
\hline \multicolumn{2}{|l|}{ Lowlands residential area } \\
\hline Medan & $24(21.6)$ \\
\hline Deli Serdang & $9(8.1)$ \\
\hline Langkat & $8(7.2)$ \\
\hline Tanjung Balai & $8(7.2)$ \\
\hline Asahan & $6(5.4)$ \\
\hline Binjai & $4(3.6)$ \\
\hline Padang Lawas Utara & $4(3.6)$ \\
\hline Aceh Singkil & $4(3.6)$ \\
\hline Labuhan Batu & $3(2.7)$ \\
\hline Batubara & $3(2.7)$ \\
\hline Nias & $2(1.8)$ \\
\hline Gunung Sitoli & $2(1.8)$ \\
\hline Tapanuli Selatan & $2(1.8)$ \\
\hline NAD & $2(1.8)$ \\
\hline Aceh Utara & $2(1.8)$ \\
\hline Aceh Tamiang & $2(1.8)$ \\
\hline Padang Sidempuan & $1(0.9)$ \\
\hline Tebing Tinggi & $1(0.9)$ \\
\hline Serdang Bedagai & $1(0.9)$ \\
\hline Langsa & $1(0.9)$ \\
\hline Aceh Timur & $1(0.9)$ \\
\hline \multicolumn{2}{|l|}{ Highlands residential area } \\
\hline Karo & $5(4.5)$ \\
\hline Simalungun & $4(3.6)$ \\
\hline Toba Samosir & $3(2.7)$ \\
\hline Aceh Tenggara & $3(2.7)$ \\
\hline Tapanuli Utara & $2(1.8)$ \\
\hline Pematang Siantar & $2(1.8)$ \\
\hline Pakpak Bharat & $1(0.9)$ \\
\hline Humbang Hasundutan & $1(0.9)$ \\
\hline \multicolumn{2}{|l|}{ Indoor workers } \\
\hline Housewife & $38(34.2)$ \\
\hline Entrepreneur & $23(20.7)$ \\
\hline Civil servants/Employees & $12(10.8)$ \\
\hline Student & $7(6.3)$ \\
\hline Unemployment/Retired & $6(5.4)$ \\
\hline Midwife & $2(1.8)$ \\
\hline Teacher & $1(0.9)$ \\
\hline \multicolumn{2}{|l|}{ Outdoor workers } \\
\hline Farmer & $20(18)$ \\
\hline Merchant & $2(1.8)$ \\
\hline
\end{tabular}

\section{Discussion}

From 111 patients, 75 of them were women $(67.7 \%)$, while men were 36 people $(36.4 \%)$. This result is consistent with the research conducted by Mohan and Letha (2017) in Kerala, South India, and Hui et al.,

Table 3: Chi-square analysis, contingency coefficient, and prevalence ratio between types of eyelid tumors with gender, age group, occupation, and residential area

\begin{tabular}{|c|c|c|c|c|c|}
\hline \multirow{2}{*}{$\begin{array}{l}\text { Independent } \\
\text { variables }\end{array}$} & \multicolumn{2}{|c|}{ Types of eyelid tumor } & \multirow[t]{2}{*}{$\mathrm{PR}(95 \% \mathrm{Cl})$} & \multirow[t]{2}{*}{$p$-value } & \multirow[t]{2}{*}{$r$} \\
\hline & $\begin{array}{l}\text { Malignant } \\
\text { tumor } \mathrm{n}(\%)\end{array}$ & $\begin{array}{l}\text { Benign tumor } \\
\mathrm{n}(\%)\end{array}$ & & & \\
\hline \multicolumn{6}{|l|}{ Gender } \\
\hline Male & $23(19.5)$ & $13(16.5)$ & 1.5 & \multirow[t]{2}{*}{0.150} & \multirow[t]{2}{*}{0.135} \\
\hline Female & 37 (40.5) & $38(34.5)$ & $(0.85-2.65)$ & & \\
\hline \multicolumn{6}{|l|}{ Residential area } \\
\hline Highlands & $48(48.6)$ & $42(41.4)$ & 1.13 & \multirow[t]{2}{*}{0.752} & \multirow[t]{2}{*}{0.03} \\
\hline Lowlands & $12(11.4)$ & $9(9.6)$ & $(0.52-2.47)$ & & \\
\hline \multicolumn{6}{|l|}{ Occupation } \\
\hline Indoor worker & $44(48.1)$ & $45(40.9)$ & 2.26 & \multirow[t]{2}{*}{$0.05^{\star}$} & \multirow[t]{2}{*}{0.183} \\
\hline Outdoor worker & 16 (11.9) & $6(10.1)$ & $(0.95-5.36)$ & & \\
\hline \multicolumn{6}{|l|}{ Age group } \\
\hline$<50$ years & $12(25.9)$ & $36(22.1)$ & \multirow[t]{2}{*}{$\begin{array}{l}2.72 \\
(1.74-4.23)\end{array}$} & \multirow[t]{2}{*}{$0.001^{*}$} & \multirow[t]{2}{*}{$0.454^{\star *}$} \\
\hline$>50$ years & $48(34.1)$ & $15(28.9)$ & & & \\
\hline
\end{tabular}


(2017) in Bandung, Indonesia, where the majority of patients are women [5], [7]. However, other countries have different results, such as in Bali, Indonesia, there are more men than women $59.1 \%: 40.2 \%$ and in the city of Ahmadabad, India, men are $57.82 \%$ while women are $42.18 \%$ [3], [8]. There is no known cause of a higher incidence of eyelid tumors in women, but some researchers suspect an increased incidence of eyelid tumors in women due to the use of excessive sun cream on the eyelid area and long-term use of oral contraceptives or hormone replacement therapy [7], [9]. The $p$ value obtained is $0.15(p>0.05)$ which means there is no correlation between the occurrence of eyelid tumors and gender. The correlation was also very low, where r obtained $0.135(0.1-0.19=$ low degree $)$ and the risk factor for men was 1.5 times greater than female $(\mathrm{PR}=1.5,95 \% \mathrm{Cl}=0.85-2.65)$.

The most dominant age group is $51-60$ years, which is as many as 34 patients $(36 \%)$. These results were consistent with research conducted in Ankara, where patients with eyelid tumor were at most 40 years old and the study conducted in Bandung found that the majority of patients were over 60 years of age [2], [8]. This fits with the theory that as we get older, the duration of exposure to carcinogenic substances also increases [3]. From the analysis, it was found that the age group above 50 years was 2.72 times greater of developing eyelid tumors $(\mathrm{PR}=2.72,95 \% \mathrm{Cl}=1: 47$ to $4: 23$ ). In addition, the $p$-value obtained was 0.001 $(p<0.05)$ which was significant. The correlation value obtained based on age group data is 0.454 , which means the correlation strength is moderate $(0.4-0.59)$.

The majority of patients with eyelid tumors indoor workers, such as housewives, as many as 38 people (34.8\%). These results contradict with research conducted in Bali, where the majority of patients were outdoor workers and research in Croatia, where outdoor workers $(72.4 \%)$ are more susceptible to tumors associated with skin in the head area, in this case, the eyelids [3], [10]. From research conducted in Sweden, indoor workers have the same risk of skin tumors as high as outdoor workers due to repeated and prolonged sun exposure to indoor workers who do outdoor work in their daily activities, leisure time, or during the holiday [11]. Moreover, in Indonesia, indoor workers (e.g., housewives, employees, etc.) often perform daily activities outdoors also Indonesia lies on the equator, so this contributes in increasing the risk of eyelid tumors in indoor workers. Nonetheless, the risk factors for eyelid tumors were 2.26 times greater for outdoor workers $(\mathrm{PR}=2.26,95 \% \mathrm{Cl}=0.95-5.36)$. The $p$-value obtained is $0.05(p<0.05)$ which means there is a relationship between the type of work and the occurrence of eyelid tumors. While the correlation value is 0.183 , which means that the correlation strength is very low (0-0.19).

Malignant eyelid tumors are the most common type in this study. These malignant tumors are BCC, which is 30 cases from 111 medical records. This because prolonged exposure to ultraviolet (UV) light is one of the main risk factors for $\mathrm{BCC}$, in addition, the incidence of $\mathrm{BCC}$ will increase in the equatorial region because exposure to UV light in this region is very intense [12], [13], [14], [15]. Theory is in line with the previous study in Saudi Arabia, where the incidence of BCC is low due to national customs and traditions [16].

Patients in this research mostly reside in the lowlands, which is in Medan city, as many as 24 people $(21.4 \%)$. These results contradict the theory which states that in the highland areas, the intensity of UV exposure will increase, this also applies to regions with tropical climates and located in the equatorial region. Moreover, people who lived on the equator often wear thin so that longer exposure to sunlight causes a greater risk of skin cancer [6]. This statement was not entirely contradictory because Indonesia is located on the equator and has a tropical climate. Hence, patients who live in the highlands or lowlands have equally high risk. However, in terms of risk factors, people living in highland areas were 1.13 times more likely to develop eyelid tumors $(P R=1.13,95 \% \mathrm{Cl}=0.52-2.47)$. The $p$-value obtained was 0723 ( $p>0.05)$, which means there is no relationship between the residential area with eyelid tumors. Other than that, the $r$ value is 0.03 . This means that the correlation between tumor eyelids with residential areas is very low (0-0.19).

\section{Conclusion}

Age and occupation have a correlation with the occurrence of an eyelid tumor, while gender and residential have not correlated. Therefore, it is highly recommended that people who live in the equatorial area (such as Indonesia, Southeast Asia countries) and living in the highland area be given education about the use of sun protection in their daily activities indoors or outdoors and the use of sun protection is highly recommended for adults over 30 years old.

\section{References}

1. American Academy of Ophthalmology. Orbit, Eyelids, and Lacrimal System. Sec 7. San Francisco: American Academy of Ophthalmology; 2015.

2. Gundogan F, Yolcu U, Tas A, Sahin OF, Uzun S, Cermik H, et al. Eyelid tumors: Clinical data from an eye center in Ankara, Turkey. Asian Pac J Cancer Prev. 2015;16(10):4265-9. https:// doi.org/10.7314/apjcp.2015.16.10.4265 PMid:26028084

3. Yuliawati P, Piliantari-Meigawati NL. Eye tumor patients at tumour division eye clinic Sanglah general hospital Bali-Indonesia. Bali 
Med J. 2013;2(2):64-8.

4. Ardjaja YK, Yuliawati $P$, Djelantik AA, Triningrat AA, Utari NM Karakteristik penderita ocular surface squamous neoplasia di RSUP Sanglah Denpasar tahun 2013-2015. Medicina 2017;48(3):157-62. https://doi.org/10.15562/medicina.v48i3.144

5. Mohan BP, Letha V. Profile of eye lid lesions over a decade: A histopathological study from a tertiary care center in South India. Int J Adv Med. 2017;4(5):1406-11. https://doi. org/10.18203/2349-3933.ijam20174293

6. D'Orazio J, Jarrett S, Amaro-Ortiz A, Scott T. UV radiation and the skin. Int J Mol Sci. 2013;14(6):12222-48. https://doi. org/10.3390/ijms140612222

PMid:23749111

7. Hui YS, Kartiwa RA, Dwiwina RG. Characteristics of malignant eyelid basal cell carcinoma in cicendo eye hospital Bandung from 2013 to 2015. Althea Med J. 2017;4(1):148-51. https://doi. org/10.15850/amj.v4n1.1037

8. Anandani MG, Parikh BS, Shah RN. Histopathological study of eyelid lesions. Natl J Lab Med. 2018;7(1):7-11.

9. Kuklinski LF, Zens MS, Perry AE, Gossai A, Nelson $\mathrm{HH}$, Karagas MR. Sex hormones and the risk of keratinocyte cancers among women in the United States: A population-based casecontrol study. Int J Cancer. 2016;139(2):300-9. https://doi. org/10.1002/ijc.30072

PMid:26941014

10. Orkić Ž, Puntarić D, Vidosavljević D, Puntarić I, Gvozdić V, Mayer D, et al. Climatic factors and epidemiologic characteristics of head and neck skin malignancies in Osijek Baranja county, Croatia. Cent Eur J Public Health. 2015;23(4):275-85. https:// doi.org/10.21101/cejph.a4075
PMid:26841139

11. Lindelöf B, Lapins J, Dal H. Shift in occupational risk for basal cell carcinoma from outdoor to indoor workers: A large population-based case-control register study from Sweden. Acta Derm Venereol. 2017;97(7):830-3. https://doi. org/10.2340/00015555-2660

PMid:28358170

12. Shi $Y$, Jia R, Fan X. Ocular basal cell carcinoma: A brief literature review of clinical diagnosis and treatment. OncoTargets Ther. 2017;10:2483-9. https://doi.org/10.2147/ott.s130371

PMid:28507440

13. Zargaran $M$, Moghimbeigi A, Monsef A, Teimourian $H$, Shojaei S. A clinicopathological survey of basal cell carcinoma in an Iranian population. J Dent (Shiraz). 2013;14(4):170-7. PMid:24724141

14. Totir M, Alexandrescu C, Pirvulescu R, Gradinaru S, Costache M. Clinical, histopathological and therapeutical analysis of inferior eyelid basal cell carcinomas. J Med Life. 2014;7(4):18-22. PMid:27057245

15. Bagheri A, Tavakoli M, Kanaani A, Zavareh RB, Esfandiari H, Aletaha $M$, et al. Eyelid masses: A 10-year survey from a tertiary eye hospital in Tehran. Middle East Afr J Ophthalmol. 2013;20(3):187-92. https://doi.org/10.4103/0974-9233.114788 PMid:24014978

16. Manar AW, Reem AA, Dala AE, Azza M, Rajiv K, Eman AS, Hind AK, et al. Characteristics and factors related to eyelid basal cell carcinoma in Saudi Arabia. Middle East Afr J Ophthalmol. 2018;25(2):96-102.

PMid:30122855 